\title{
JOHANNES CALVYN OOR GEBEDSVERHORING
}

\author{
P.C. Potgieter ${ }^{1}$
}

\begin{abstract}
Calvin has written extensively on prayer, not only in his Institutes, but also in his commentaries, sermons and letters. His views in this regard have been reflected in a substantial number of publications by various Calvin scholars. This article particularly researches his views on God's answering of prayer, on which relatively little has been published yet. Some of Calvin's views in this regard may be debatable — for instance his huge and often repeated emphasis on repentance as primary element of prayer, and his view that in delaying his answer to our prayers God is exercising us in patience. On the other hand he has said much that may currently be of significant importance for theology, and particularly for the pastoral care of the faithful in their search for understanding the ways of God.
\end{abstract}

\section{INLEIDING}

Gebedsteleurstelling. Dit is onbetwisbaar deel van baie gelowiges se ervaring. Andrew Murray was volkome korrek toe hy in sy werk oor die geestelike lewe onder andere gesê het: "One of the biggest obstacles to prayer is that the answer does not come as speedily as we expect" (Murray 2004: 18 Junie). En tog is dit merkwaardig dat daar in die Bybel slegs enkele spesifieke gevalle genoem word waar gebede nie verhoor is soos die bidder gevra het nie. Moses sê vir die volk:

Maar deur julle toedoen het die Here destyds vir my kwaad geword en daarom het Hy nie nou my gebed verhoor nie (Deut. 3:26).

Christus het gebid en gevra dat die lydensbeker by Hom moet verbygaan (Matt. 26:39), maar dit is nie aan Hom gegee nie. Paulus het die Here drie maal gebid dat die "doring in die vlees" van hom af weggeneem moet word - maar dit is nie aan hom toegestaan nie. Maar selfs waar dit só gebeur het, is daar ook weer nie uitdruklik sprake van teleurstelling nie. Wat God gedoen het, is deur die bidders aanvaar. Dit is wat die Bybel vertel van spesifieke gevalle waar mense se gebedsversoeke nie toegestaan is nie.

1 Prof. Pieter C. Potgieter, Navorsingsgenoot, Departement Dogmatologie, Fakulteit Teologie, Universiteit van die Vrystaat, Bloemfontein. 
Daar is wel ' $n$ ander kant. Veral in die Psalms is daar tog weer talle duidelike situasies waar die digter pleit om verhoor te word klaarblyklik omdat die verhoring van vorige gebede uitgebly het. Habakuk kla ook: "Hoe lank moet ek om hulp roep voordat U hoor, Here ...?" (1:2). Daar is ook die gelykenis van die regter en die weduwee (Lukas 18:1-8), waaruit duidelik blyk dat daar inderdaad soms vertraging in die verhoring van gebed kan wees. Dit alles in ag genome, bly die probleem van gebedsverhoring en die teleurstelling wat dikwels daarmee gepaard gaan, vir baie gelowiges 'n probleem wat selfs tot 'n geloofskrisis kan ontwikkel.

Johannes Calvyn laat hom in talle van sy werke uit oor gebedsverhoring en probleme wat daarmee saamhang. Hy weerhou hom egter daarvan om in dié verband pertinent na teleurstelling te verwys, alhoewel dit meermale uit die konteks duidelik is dat sy hoorders of lesers dit klaarblyklik so ervaar het. Wat hy hieroor gesê het, is belangrik genoeg om deeglik van kennis te neem. Dat hy hom op 'n pastorale en baie praktiese wyse met die oog op die daaglikse geloofslewe uitgelaat het, is nie vreemd nie. Partee wys met nadruk daarop dat daar 'n wesenlike verhouding is tussen "Calvin the Christian believer and Calvin the Christian theologian"; tussen sy ortodoksie en ortopraksie (Partee 1988:245).

Calvyn handel breedvoerig oor gebed in Boek 3 van die Institusie (hoofstuk 20). Afgesien van sy behandeling van die Nagmaal, is daar, trouens, in die hele Institusie geen ander enkele onderwerp waaraan hy meer aandag bestee nie. Dit is dus nie vreemd dat daar reeds heelwat gepubliseer is oor Calvyn se gebedsbeskouing nie. ${ }^{2}$ Oor die spesifieke onderwerp van gebedsverhoring by Calvyn is die literatuur egter merkwaardig beperk tot korter verwysings of enkele paragrawe in publikasies wat oor spiritualiteit of gebed by Calvyn handel.

\section{GEBEDSGESINDHEID}

Oor Calvyn se breër gebedsbeskouing kan hier dus met enkele opmerkings volstaan word. Niesel kom tot die oortuiging dat Calvyn die essensie van gebed sien "als ein Ausbreiten unseres Herzens vor Gott"

2 Vgl. byvoorbeeld die werk van H. Scholl, Der Dienst des Gebetes nach J. Calvin (1968, Zurich: Zwingli). 
(Niesel 1938:145; vgl. CR 37, 402). Maar gebed is ook in 'n sekere sin die gesprek van 'n mens met $\mathrm{God}^{3}$ waardeur iemand persoonlik met Hom kan praat op grond van sy beloftes (Inst. 3.20.2). Gebed is ook 'n geloofsoefening: die opskrif bo die betrokke hoofstuk in die Institusie lui immers: De oratione, quae praecipuum est fidei exercitium, et qua Dei beneficia quotidie percipimus. Hy sê ook pertinent dat dit "nie 'n geringe geloofsoefening is om die dinge van God te verwag wat ons andersins so bekommerd maak nie" (Inst. 3.20.44; vgl. Wallace 1959:271). Gelowiges bid sodat hulle hulleself kan aanspoor om Hom te soek, dat hulle hulle geloof mag oefen (fidem suam execeant) wanneer hulle nadink oor sy beloftes, dat hulle ontslae kan raak van hulle angste deur dit aan Hom toe te vertrou; kortom, dat hulle sal toon dat hulle op Hom alleen hoop en van Hom alleen alles wat goed is (quidquid est bonorum) verwag — vir hulleself en vir ander (Komm. Matt. 6:8; ${ }^{4} \mathrm{CO}$ $45,193 v$ v.). Wallace vat hierdie gebedsdefinisies van Calvyn saam as

the genuine cry of the human heart for help in the midst of circumstances that cannot be met by merely human resources (Wallace 1959:280). ${ }^{5}$

Wat meteens opval by die nalees van Calvyn oor die gebed, is sy besondere nadruk op die gesindheid van die bidder. Afgesien van eerbied vir God — wat voor alles kom — moet die bidder altyd sy eie hulpeloosheid ken en erken. ' $n$ Opregte gebed vereis dus boetvaardigheid $^{7}$ (Inst. 3.20.7; vgl. Komm. Joh. 9:31; CO 47,230), en dit is slegs opregte dienaars van God wat behoorlik bid en verhoor word (vgl. CO 55,343). Daarom sê hy:

Die begin en selfs ook die voorbereiding vir 'n behoorlike gebed is 'n pleidooi om genade met 'n ootmoedige en opregte skuldbelydenis (cum bumili et ingenua culpae confessione, OS IV, 306). ${ }^{8}$

3 "Est enim quaedam hominum cum Deo communicatio" (OS IV, 297).

4 Komm. dui aan Calvyn se Kommentaar op die spesifieke Skrifverwysing. Daar is hoofsaaklik gebruik gemaak van Kommentare in The Ages Digital Library: Books for the Ages. AGES Software - Albany, OR USA.

$5 \quad$ Vgl. Komm. Jer. 29:13. "Quaerendi autem ratio, ubi opus habemus Dei gratia, non alia est quam precari" (CO 38:595).

6 "Esto et altera lex, ut rogando semper inopiam nostram vere sentiamus ..." (OS IV, 302).

7 "Itaque poenitentiam legitima oratio postulat" (OS IV 304)

8 Die gebed wat Calvyn gewoonlik voor die prediking gedoen het, begin so: 
In die Kategismus van die Kerk van Genéve (1545) — wat sonder twyfel deur Calvyn opgestel is - word hierdie gebedsgesindheid net so sterk benadruk (Calvin 1958:71). Die gelowige behoort altyd met 'n gesindheid van vrees en bewing voor God te kom (Vgl. Wallace 1959:273 en Inst. 3,20,11). Daarom moet gebede altyd begin met die belydenis van skuld - nie net vir die sondes van die huidige dag waaraan die bidder kan dink nie, maar ook vir sondes wat lyk asof hulle lank reeds vergete is en vir die sondigheid van sy natuur (Inst. 3,20,9). Battles gee 'n sinvolle verklaring vir hierdie benadering van Calvyn:

We may be overwhelmed by the sheer weight of assertions about human sin and inability voiced in the prayers of his liturgy. But this was the way the Reformer chose to drive home to his flock the lessons of sola gratia. Only the shock of exaggeration and constant reiteration could bring to the common Christians the force, the insights of the new Augustinianism or, more precisely, the renewed evangel of the Protestant Reformation (Battles 1978:9).

Daarom stel Calvyn dit herhaaldelik dat diegene wat met die regte gesindheid tot God bid, dit kan doen in die vaste vertroue dat Hy altyd hoor en verhoor. Hulle moet dit glo. God word, trouens, nie reg en in geloof aangeroep nie tensy ons ten volle oortuig is dat ons gebede nie tevergeefs sal wees nie (nisi quum certo persuasi sumus non irritas fore nostras preces, Komm. 1 Joh. 5:14; CO 55,370. Vgl. ook Komm. Hand. 8:22; CO 48,186-7).

Aan die ander kant is dit 'n algemene waarheid wat in die Skrif geleer word dat die goddelose nie deur God verhoor word nie (Inst. 3.20.7). Inteendeel: hulle offerandes en gebede is vir Hom 'n gruwel (Komm. 1 Joh. 3:22; CO 55,343). Niemand is geskik om tot God te bid as sy hart nie eers deur geloof gereinig is nie (Komm. Joh. 9:31; CO 47,230). ${ }^{9}$

Alhoewel Calvyn die regte gebedsgesindheid so sterk beklemtoon en dit inderdaad as voorwaarde stel, sê hy ook ewe duidelik dat die rede

Laat ons nader tot ons goeie God en Vader, terwyl ons Hom bid om gewillig te wees om sy aangesig weg te draai van ons groot getal foute en oortredinge, waardeur ons nie ophou om sy toorn teen ons op te roep nie, en ons ook te onwaardig is om voor sy majesteit te verskyn ... (Calvin 1996:623).

9 "In summa, nemo ad Deum orandum rite est comparatus, nisi qui cor fide purgatum babet" (CO 47,230). 
vir die verhoring van ons gebede nie daarin gesoek moet word nie, maar in God self. Dit is eie aan die God-wees van God dat Hy die verhoorder van gebede is (vgl. 10 ${ }^{\text {de }}$ Preek oor Ps. 119, CO 32,596). Daar is geen sprake van verdienste by die verhoring van gebede nie - hoe opreg hulle ookal mag wees. God luister en verhoor uit genade (Vgl. Komm. Jes. 38:5; CO 32,651). Wallace meen dat daar geen twyfel hieroor kan wees nie:

From an examination of many of the prayers of the Bible Calvin proves that the confidence of man who prays is based solely on the mercy of God (Wallace 1959:274).

Die verhoring van ons gebede word gewaarborg deur die feit dat $\mathrm{Hy}$ in 'n sin sy eie aard (naturam suam) sou ontken indien Hy dit van die hand sou wys. Die Psalmdigter sê nie bloot dat God in een of ander geval die gebed verhoor het nie, maar noem Hom die verhoorder van gebed, ${ }^{10}$ wat 'n blywende deel van sy heerlikheid is, sodat Hy net so goed Homself kan verloën as om sy ore te sluit vir ons smekinge ... Dit is iets eie aan en onvervreembaar (inseparabile) van God om gebede te verhoor. As ons dit maar net vir onsself kan inskerp, sal dit by ons 'n onwankelbare vertroue wek (Komm. Ps. 65:2; CO 31,603).

Calvyn sê dat niks pragtiger is as dat God Homself so aan ons voorstel sodat ons seker kan wees dat "niks meer eie is aan sy aard as om die wense van die wat Hom smeek, te vervul nie" (Inst. 3.20.13). Hierdie siening van Calvyn kom ook aan die orde in die slot van sy verklaring van die Ons Vader in die Institusie:

Aan die einde word bygevoeg: Amen. Daarmee word die vuur van ons verlange om te kry wat ons God gebid het, uitgedruk en ons hoop versterk dat al die dinge van hierdie aard reeds verkry is en gewis aan ons gegun sal word omdat dit deur God beloof is, wat nie kan bedrieg nie. ... Hiermee druk die heiliges nie alleen die doel van hulle begeertes uit nie, maar hulle erken ook dat hulle nie waardig is om dit te verkry nie tensy God die rede om dit te doen uit Homself neem en dat hulle vertroue om verhoor te word uit God se natuur alleen (ex sola Dei natura) kom (Inst. 3.20.47; OS IV,365).

$\mathrm{Na}$ aanleiding van Psalm 145:19 (Hy hoor as hulle om hulp roep, en Hy red hulle) stel Calvyn dat God die gebede van die wat aan Hom behoort, verhoor om daadwerklik te bewys dat Hy die betroubare beskermer van hulle welsyn is (fidem esse salutis eorum custodem, CO 32,420). 
Afgesien daarvan dat Hy vanweë sy Goddelike natuur die Verhoorder van gebede is, word gebedsverhoring gewaarborg deur talle beloftes van God. Sulke beloftes is egter ook meermale aan die opdrag tot gebed verbind:

Tot hierdie kennis van ons eie gebrekkigheid het die allerbeste Vader twee dinge toegevoeg om ons heftig tot gebedsywer te dryf, naamlik 'n bevel waarvolgens $\mathrm{Hy}$ ons beveel om te bid, en 'n belofte waarvolgens Hy belowe dat ons sal kry wat ons vra. Ons het sy bevel wat baie dikwels herhaal word: "Soek"; "Kom na My toe", "Vra My"; "Wend julle tot My"; "Roep My aan in die dag van julle nood". ... As ons daarom nie juis na Hom ons toevlug neem wanneer die een of ander nood ons druk nie, as ons Hom nie soek en om sy bystand smeek nie, verwek ons sy toorn net asof ons vir ons vreemde gode mak of afgodsbeelde oprig, aangesien ons in die minagting van al sy gebooie sy wil ewe veel minag (Institusie 1536:170; CO 1,83).

Hiervoor beroep Calvyn hom op Psalm 50:15, ${ }^{11}$ Psalm 91:15, Psalm 145:18 en Jesaja 65:24. ${ }^{12}$ Sulke uitnodigings gee aan gelowiges die sekerheid dat God hulle sal verhoor.

Ons gebede maak trouens op geen verdienste staat nie, maar hulle aansien en die hoop om te verkry (wat ons vra) is in God se beloftes gegrond en daarvan afhanklik (Inst. 3.20.14).

Ons mag weet dat God nie teruggaan op wat Hy besluit en belowe het nie (Preek oor Deut. 9:13-14; CO 26,682).

\section{CHRISTUS ONS VOORSPRAAK}

Calvyn wys ook daarop dat daar veral een belofte van buitengewone betekenis is. Wat ons in die Naam van Christus vra, sal ons verkry (Komm. Joh. 14:13; CO 47,327; vgl. ook Komm. 1 Joh. 3:22; CO 55,343). Ons het trouens 'n besondere opdrag om God in Christus se Naam aan te roep. Dit is Christus se tussentrede wat God se troon van skrikwekkende heerlikheid verander in 'n troon van genade (Inst. 3.20. 17). Waar hy Christus se priesterlike amp hanteer, sê hy: dat dit verhoor sal word en daarna 'n oproep tot dankbetuiging (CO 31 , 502).

12 "Hier belowe God dat ons nie tevergeefs sal bid nie" (non frustra pecaturos, CO $37,432)$. 
Hieruit volg dat Hy vir ewig ons Voorbidder is, deur wie se voorspraak ons God se guns verkry. Daaruit spruit nie alleen vertroue om te bid nie maar ook rustigheid vir die gewete van godvrugtiges ... (Inst. 2.15.6; vgl. Tyson 1999:387).

In sy vierde preek oor die hemelvaart van ons Here Jesus Christus (Hand. 1:9-11) verseker Calvyn die gemeente dat ons nie met twyfel in die hart tot God hoef te bid nie, want "ons kan seker wees dat ons gebede altyd aanneemlik sal wees vir Hom, omdat ons deur Jesus Christus bid" (CO 48,613v.). Na aanleiding van Johannes 16:26 stel Calvyn dit mooi: Ons het die hart van ons hemelse Vader (le coeur du Pere celeste) sodra ons die Naam van sy Seun voor Hom gebring het (Comm. ad loc.; CO 47,371).

Aan die ander kant moet ons weet dat elke gebed wat nie deur Christus se tussentrede gesteun word nie, afgewys word (repudiari, Komm. Heb. 7:26; CO 55,95). ${ }^{13}$

\section{GELOOFSVERTROUE AS VOORWAARDE}

Calvyn laat herhaaldelik blyk dat gebed sonder geloofsvertroue 'n hopelose saak is. In die Kategismus van die Kerk van Genéve moes die katkisant oor gebedsverhoring antwoord dat die grondslag van ons gebed altyd moet wees dat die Here ons sal hoor en dat ons sal kry wat ons ookal vra, in soverre dit vir ons goed is (Calvin 1958:72). Ons moet die hemelse troon met vertroue nader om genade te verkry.

As ons met vrug wil bid, moet ons derhalwe hierdie onbesorgdheid $^{14}$ oor die verkryging van dit waarvoor ons bid, met albei hande vashou, want die Here het ons self so beveel en al die heiliges leer ons dit met hulle voorbeeld. 'n Gebed is immers eers vir God aanvaarbaar as dit, om dit so te stel, uit die hardnekkigheid van die geloof (ex tali praesumptione fidei) ontstaan en in die onbeskroomde sekerheid van die hoop (intrepida spei certitudine) gegrond is (Inst. 3.20.12; OS IV,311).

13 In 'n brief van 22 Augustus 1553 aan Denis Peloquin en Louis de Marsac wat die doodstraf in die gevangenis afgewag het vanweë hulle geloofsoortuiging, ondersteun Calvyn hulle belydenis dat ons God met die sekerheid van die geloof net in die Naam van Christus mag aanroep (CO 14,5930).

14 securitatem; dit sou ook as gemoedsrus vertaal kon word. 
Selfs wanneer ons deur omstandighede platgeslaan is, moet ons nogtans deur die vaste hoop op verhoring besiel word om te bid. Ons moet in ootmoed besef dat ons niks verdien nie, want juis so is boetvaardigheid en geloof bondgenote wat mekaar in ons gebede moet ontmoet (ita in precibus mutuo eas occurrere oportet, Inst. 3.20.11; OS IV,309). Ten spyte van teenslae en bekommernis oor moontlike nuwe rampe, moet die godvrugtige mens tog tegelyk sy toevlug tot God neem en hoegenaamd nie daaroor twyfel dat Hy gereed is om hom 'n helpende hand te reik nie (Inst. 3.20.11).

Ons moet dus glo voordat ons bid, want wie nie geloof in die beloftes van God het nie, se gebed is geveinsd (Komm. Jak. 1:6; CO 55,385 v.). In 'n preek oor Galasiërs 4:4-7 vermaan Calvyn weer sy hoorders dat hulle nie sonder geloof tot God kan bid as hulle wil seker wees dat Hy hulle hoor nie. Die Here stel nie die wat Hom soek teleur nie, maar as ons bid, moet ons goed verstaan wat ons van Hom afsmeek (CO 50,583vv.). As Christus sê dat ons sal ontvang waarvoor ons bid as ons dit glo, moet ons dit egter nie so verstaan dat Hy daarmee vrye teuels gee aan mense se wense sodat hulle enigiets waarvoor hulle lus het, kan begeer nie. Hy vra wel 'n ontwyfelbare vertroue om verhoor te word, maar dié vertroue kan net uit die Woord van God kom. Dit beteken dat waarvoor gebid word, dus binne die perke van God se behae moet wees (Komm. Mark. 11:24; CO 45,585).

Waar Calvyn so sterk nadruk lê op geloofsvertroue in die gebed, is die belangrike vraag wat die inhoud van daardie geloof moet wees. Selfs wanneer hy praat van die "hardnekkigheid van die geloof", van die "sekerheid van die hoop" (Inst. 3.20.12; OS IV,311), van 'n "vaste hoop op verhoring" (Inst. 3.20.11; OS IV,309) en van 'n "ontwyfelbare vertroue om verhoor te word” (Komm. Mark. 11:24; CO 45,585), bly hy versigtig in sy formulering, sodat die afleiding nie gemaak moet word dat hy bedoel dat die gelowige gebed presies soos die bidder vra, verhoor sal word nie. Wat die bidder wel moet glo, is dat God by magte is om sy gebed te verhoor, en dat Hy dit sal doen op die wyse wat in alle opsigte die beste is. 


\section{VERTRAAGDE VERHORING EN VOLHARDING IN DIE GEBED}

Calvyn was terdeë bewus van die vrae waarmee gelowiges dikwels rondom gebedsverhoring geworstel het. Hy het hierdie kwessies dus ook pertinent in sy prediking aangeraak. So wys hy in sy preek oor Matteus 26:40-50 daarop dat die Here Jesus self in Getsemane herhaaldelik gebid het.

Daardeur sien ons in sy voorbeeld dat Hy ons aangemoedig het om nie te verflou as ons nie so gou as ons wou hê, verhoor word nie.

Om jou toevlug tot God te neem, hou allereers volharding in. Ons heel eerste geloofsoefening (le principal exercice de nostre foy) is dus gebed, want geloof kan nie bestaan sonder vertraging nie (or la foy ne peut estre sans attente). Dit is noodsaaklik dat die Here ons laat wag en dat Hy ons soms laat smag (na verhoring) sodat ons sal weet wat dit is om Hom opreg en sonder voorwendsel aan te roep (CO 46,846-59).

In 'n troosbrief aan die gemeente van Genéve (1 Oktober 1538) skryf hy dat hulle tog moet verstaan dat wanneer God versuim om dadelik die begeerte van sy kinders toe te staan en Homself nie onmiddellik betoon in die oomblik as hulle uitkoms nodig het nie, dit gewoonlik is omdat Hy hulle wil aanmoedig om vir sy guns te smeek. Met hulle gebede moet hulle bewys dat hulle werklik hulle toevlug tot Hom neem. Hy bid self "die Here van alle vertroosting om julle te versterk en te dra in geduld" (CO 10.2,555). In 'n ander brief (21 Junie 1546) aan Madame de Falais wat ernstig siek was, skryf Calvyn dat ons God moet bid om ontferming onder sulke moeilike omstandighede, maar dat "ons geduldig moet wag op uitkoms soos dit Hom mag behaag (Calvin 2000:Vol. 5,63). Op 8 Desember van dieselfde jaar skryf hy ook aan Monsieur de Falais. In dié brief gaan dit oor militêre en politieke kwessies. Hy roep hom op tot gebed en om tevrede te wees met wat God gee, want ons moet weet "dat dit God behaag om tot ons voordeel ons geduld op die proef te stel" (Calvin 2000:Vol. 5,95).

In 'n ander brief aan 'n onbekende dame wat deur moeilike omstandighede gaan, skryf hy:

Dis waar, Hy laat ons soms moeg word, en voordat Hy duidelik laat blyk dat Hy ons gebede gehoor het, lyk dit asof $\mathrm{Hy}$ op 'n afstand bly staan, net soseer om ons begeerte groter te maak as om ons 
geduld op die proef te stel. Daarom moet jy nie dink dat jou gebede tot Hom sover tevergeefs was nie; skep eerder moed en beywer jou al meer terwyl jy weet dat volharding ons lewe lank van ons vereis word — veral in gebed (Calvin 2000:Vol. 5, 217).

In die Institusie sê hy dat ons hemelse Vader soms

die indruk skep dat Hy wel sluimer of slaap, naamlik om ons, wat andersins traag en lui is, tot ons eie groot voordeel te oefen om Hom te soek, van Hom te vra en van Hom af te bid (Inst. 3.20.3).

Ons moet ook weet dat die Here die wat aan Hom behoort nie met ligte beproewings beproef nie en hulle ook nie sagkens oefen nie,

maar Hy dryf hulle dikwels tot die uiterste toe, en wanneer hulle daarheen gedryf is, laat Hy hulle lank in die slyk bly voordat Hy hulle enige smaak van sy soetheid bied (Inst. 3.20.52).

Hy sê ook dat gelowiges se gebrekkige gebede veral die gevolg is van die swakheid of onvolkomenheid van hulle geloof.

Dit is egter nie verbasend dat God hierdie gebrek vergewe nie, omdat Hy diegene wat aan Hom behoort, dikwels met harde teregwysings beproef net asof Hy hulle geloof doelbewus (data opera) wil uitdoof (Inst. 3.20.16; OS IV, 321).

Jesaja 30:19 is nie maklik te verklaar in terme van die vertraging van gebedsverhoring nie. Dit sê immers uitdruklik:

Die Here sal jou genadig wees as jy na Hom roep om hulp, Hy sal jou gebed verhoor sodra Hy dit hoor.

Dit is merkwaardig dat Calvyn die Hebreeuse כשמעתו vertaal met respondebit, wat nie soseer verhoor nie, maar eerder antwoord beteken. Daarom kan hy goedskiks sê dat dit niks anders beteken nie as dat Hy bewys sal lewer van sy goedheid en hulp, want die Here "antwoord" nie by wyse van 'n woord nie, maar met die daad.

Ons moet egter nie dink dat Hy oombliklik aan ons wense sal voldoen nie, want dit is dikwels oorhaastig en ontydig. Hy sal ons ongetwyfeld help as die regte tyd aanbreek, sodat ons sal weet dat Hy ons heil in die oog gehad het (CO 36,504 en 520).

In sy Kommentaar op Jesaja 65:24 antwoord Calvyn op die vraag waarom daar dan nie 'n sigbare resultaat op ons gebede is nie. 
Alhoewel dit eers volkome duidelik is dat ons verhoor is as die gebeurtenis dit in werklikheid bewys, ignoreer God ons intussen tog nie; Hy laat ons nie toe om moedeloos te word nie, maar ondersteun ons deur die krag van sy Gees, sodat ons geduldig vir Hom kan wag. Hy vertraag (die verhoring) ook nie omdat Hy tyd nodig het nie, maar omdat Hy ons wil oefen en ons geduld op die proef wil stel (CO 37 , 432).

Uit die gelykenis van die weduwee en die regter lei Calvyn af waarom God ons soms lank in afwagting hou: Hy doen dit met 'n vaderlike bedoeling, naamlik om ons in geduld te oefen. Ons ongeduld en vleeslike besorgdheid lei ons tot die slotsom dat Hy nie gou genoeg uitkoms gee nie. As ons egter insig in God se beplanning kon hê, sou ons sien dat sy bystand altyd presies op die regte tyd kom (Komm. Luk. 18:1-8; CO 45,416).

Die versoeking om op te hou bid as ons nie spoedig gehelp word nie, is altyd groot.

Dit is wat mense gewoonlik doen, wat, wanneer hulle deur hulle vuur so die hoogte in gevoer word, God so aanroep dat tensy Hy hulle met hulle eerste probeerslag bystaan en hulle onmiddellik te hulp kom, hulle hulle verbeel dat Hy vir hulle kwaad, ja, toornig is, alle hoop om verhoor te word laat vaar en ophou om Hom aan te roep.

Daar is egter talle voorbeelde in die Skrif - Dawid en ander gelowiges - wat skynbaar amper moeg geword het om te bid, maar nogtans nie daarvan afsien nie (Inst. 3.20.51). Daarom verseker Calvyn ook sy lesers dat God getrou bly:

Want al sou alles ons in die steek laat, God sal ons nooit verlaat nie omdat Hy die verwagting en lydsaamheid (expectationem ac patientiam) van die wat aan Hom behoort, nie tot niet kan laat gaan nie (Inst. 3.20.52; OS IV, 368).

Dit is duidelik dat Calvyn die vertraging in gebedsverhoring aan twee motiewe toeskryf. Enersyds doen God dit om gelowiges te oefen in hulle geloofsvertroue. Hy beproef hulle geduld om hulle daarmee tot volharding in hulle geloofsverwagting te bring. Andersyds het God soms die verhoring van gebede uitgestel omdat die regte tyd daarvoor eers moes aanbreek. Op die oog af lyk dit asof hy eersgenoemde motief swaar laat weeg het in sy pastorale hantering van mense wat deur die vertraging onseker geraak of selfs teleurgesteld gevoel het. Dit wil voorkom asof die tweede motief — wat waarskynlik vir gelowiges 
pastoraal beter sou gehelp het - nie altyd genoegsaam voorgehou is nie. Sy voorkeur kan moontlik toegeskryf word aan sy sterk gevoel oor die mens se totale verdorwenheid. Gevolglik moet eerstens gedink word aan die mens se kleingeloof en sondige ongeduld, en dan eers aan God wat ons laat wag totdat die tyd reg is.

\section{DIE WIL VAN GOD}

In 'n preek oor die verskyning van Jesus voor die Joodse Raad (Matteus 26:51-66) waar Jesus die wil van sy Vader ten opsigte van sy lyding aanvaar, sê Calvyn dat ons beslis in tye van siekte of ander kwellings mag vra vir genesing en uitkoms — juis omdat ons nie weet wat God wil nie. Maar ons moet altyd die voorwaarde byvoeg: dat sy wil mag geskied. Wanneer dit egter uit die Skrif duidelik is dat 'n bepaalde ding die wil van God is, is dit nie reg dat ons iets anders vra nie (CO 46,859-873). Trouens: die heel eerste ding wat nodig is in gebed, is konsensus met die wil van die Here (consensum cum voluntate Domini, CO 49,158).

Daarom moet ons ook slegs soveel vra as wat God ons toelaat.
Want hoewel Hy ons gebied om ons harte uit te stort, gee Hy nogtans nie onverskillig vrye teuels aan ons dwase en verkeerde begeertes nie. Wanneer $\mathrm{Hy}$ beloof dat $\mathrm{Hy}$ die wens van godvrugtiges sal uitvoer, gaan sy genade nogtans nie so ver dat Hy Hom aan hulle goeddunke onderwerp nie (Inst. 3.20.5).

Ons kan nie in geloof bid tensy ons ons begeertes temper en ons gebede beperk tot wat God vasgestel het nie (Komm. Ps. 7:7; CO 31,82 ). Elders sê Calvyn dat geloof enigiets van die Here kan verkry, want Hy heg soveel waarde daaraan dat Hy altyd gereed is om aan ons begeertes te voldoen, maar dan voeg hy meteens daarby: in die mate dat dit vir ons goed is (quoad expedit morem, $\mathrm{CO} 45,460$ ). Ook in ons gebedslewe moet die vlees oorwin word, terwyl die begeertes van die hart getemper en geïnspireer word deur die Gees, want dan word ons begeertes die werk van sy Gees en sal Hy dit nie verwerp nie (Komm. Rom. 8:27; CO 49,158).

Calvyn lewer breedvoerig kommentaar op 1 Johannes 5:14 (... omdat Hy ons gebede verhoor as ons enigiets volgens sy wil vra). 
Met die uitdrukking volgens sy wil het hy terloops bedoel om ons te herinner aan wat die regte manier of voorskrif vir gebed is, selfs wanneer mense hulle eie begeertes aan God voorlê. Want alhoewel God belowe het om te doen wat sy mense ookal mag vra, laat Hy hulle nogtans nie 'n ongebreidelde vryheid toe om te vra wat ookal in hulle gedagte opkom nie. Maar Hy het terselfdertyd vir hulle 'n reël neergelê waarvolgens hulle behoort te bid. En ongetwyfeld is daar vir ons niks beter as hierdie beperking nie. Want as elkeen van ons toegelaat was om te vra wat hy wil, en as God ons dan ons begeertes sou toegestaan het, sou dit vir ons uiters sleg wees. Ons weet immers nie wat vir ons voordelig sou wees nie; nee, ons is vol korrupte en skadelike begeertes ... Wanneer hy (Johannes) sê dat al die versoeke van gelowiges verhoor word, praat hy van regte en nederige versoeke ...(Komm. 1 Joh. 5:14, 15; CO 55,370).

As Calvyn dus aandui dat daar 'n direkte verband tussen gebedsverhoring en die wil van God is, spoor hy daardeur ook gelowiges aan om hulle te beywer om die wil van God te ken. En daarvoor is hulle aangewese op die Heilige Skrif as openbaring van sy wil.

\section{HOE GOD VERHOOR}

Calvyn haal Augustinus met goedkeuring aan ${ }^{15}$ waar hy sê dat God soms op 'n ander manier verhoor as wat ons verwag, soos Hy in sy wysheid besluit (Inst. 3.20.15). God luister op twee maniere na ons: eerstens, as Hy openlik help; en tweedens, as Hy ons ondersteun deur die krag van sy Gees, sodat ons nie wegsink onder die las van aanvegtinge nie (Komm. Jes. 65:24; CO 37,432).

In sy kommentaar op Klaagliedere 3:8, waar Jeremia kla dat hy tevergeefs bid, sê Calvyn dat ons tog weet dat God die gelowiges soms vir 'n lang tyd in afwagting hou terwyl Hy hulle hoor om só hulle geduld op die proef te stel. Selfs die gelowige praat soms volgens die mening van die vlees, terwyl God nooit die wat aan Hom behoort, verwerp of doof is vir hulle gebede en versugtinge nie. Ons moet leer uit die ondervinding van die profeet dat God soms nie gou help nie, maar dat ons gebede nogtans nooit deur Hom afgewys word nie (Comm. ad loc.). Ons moet ook nooit dink dat Christus se gebede verwerp is omdat Hy nie meteens uit sy lyding verlos is nie. Hy het uiteindelik

15 Die aanhaling uit De Civitate Dei 22.2 is nie letterlik korrek nie. Calvyn haal dit klaarblyklik uit sy geheue aan. 
gekry waarvoor Hy gebid het toe Hy as oorwinnaar oor Satan, sonde en hel uit die dood gekom het. God hoor dus ons gebede, selfs wanneer dit vir ons op geen manier duidelik is nie. Hy verhoor ons gebede in alles wat nodig is vir ons heil. En as dit oënskynlik lyk asof ons afgewys is, kry ons nogtans veel meer as wanneer Hy presies sou gee wat ons gevra het. Dit gebeur dikwels dat ons hiervoor of daarvoor vra, maar nie met die regte oogmerk nie. En tog: as God nie gee wat ons vra nie, vind Hy self' 'n weg om ons te help (Komm. Heb. 5:7; CO 55,63).

Oor Paulus se gebed oor die doring in sy vlees, laat Calvyn hom breedvoerig uit. Daar was beslis nie 'n geval van gebrek aan geloof by Paulus nie, en tog gee die Here nie wat hy vra nie sodat die apostel nie hoogmoedig sou word nie. Al het God nie aan hom gegee wat hy gevra het nie, is sy gebed beslis verhoor, maar dan soos God dit goed gevind het. Die rede waarom Hy soms genadiglik sy eie mense se versoek weier (terwyl Hy dit in sy toorn aan die goddelose toestaan), is dat $\mathrm{Hy}$ beter as wat ons kan verstaan, vooruit sien wat vir ons die beste is (Komm. 2 Kor. 12:8; CO 50,140-1).

Hierby kom nog dat al verhoor God ons, Hy nogtans nie altyd uitdruklik op die formulering van ons gebede antwoord nie, maar terwyl Hy ons oënskynlik laat wag, toon Hy nogtans op 'n manier wat vir ons onbekend is, dat ons gebede nie vergeefs was nie (Inst. 3.20.52).

God se antwoord op ons gebede is dikwels dat Hy ons innerlik sterk maak deur sy Gees (Komm. 2 Kor. 12:9; CO 50,141).

Dit is dikwels juis omdat die Here ons liefhet dat Hy ons verkeerde begeertes weier, of vir ons 'n ander antwoord gee as wat ons verwag het. Terwyl Hy dus ons versoek weier, is Hy inderwaarheid besig om ons te hoor en te verhoor; dit is net vir die goddelose wat Hy soms in sy toorn presies die antwoord gee wat hulle vleeslik gesoek het tot hulle eie verderf (Komm. Ps. 78:26; CO 31,731).

Calvyn se siening oor die wyse waarop God verhoor soos hy dit weergee in die Institusie en in sy kommentaar op verskeie Skrifgedeeltes - dat God in sy wysheid soms tot ons voordeel anders verhoor as wat ons vra - is 'n verduideliking wat met vrug in die pastoraat gebruik kan word. 


\section{DIE NOODSAAKLIKHEID VAN GEBED}

Calvyn stel dit meermale dat gebed nie nagelaat moet word nie, al weet ons dat God ons behoeftes ken nog voordat ons dit genoem het.

Hoewel die Here dus oor ons waak en oor ons wag hou, terwyl ons ongevoelig en afgestomp is vir ons ellendes en Hy ons selfs sonder dat ons Hom vra, hulp verleen, is dit daarom vir ons nogtans van die grootste belang, om Hom gedurig (assidue) aan te roep (Inst. 3.20.3; OS IV,298)

Ons hoef ook nie bekommerd te wees dat ons in ons kortsigtigheid dalk verkeerd sal bid nie.

Want na sy onbegryplike raadsplan stuur Hy die verloop van dinge so dat die gebede van die heiliges wat terselfdertyd met die geloof en met dwaling verstrengel is (quae fide et errore simul implicitae sunt), nie verniet is nie. ... Waar daar daarom geen vaste belofte van God bestaan nie, moet ons Hom voorwaardelik om iets vra (Inst. 3.20.15; OS IV,319).

Maar ons moet selfs ook as ons bid vir dinge waarvan ons weet dat dit volgens die wil van God is, versigtig wees om nie al te presies te wil voorskryf hoe en wanneer Hy ons gebede moet verhoor nie (Komm. 2 Kor. 12:8). ${ }^{16}$

$\mathrm{Na}$ aanleiding van die geskiedenis van koning Hiskia se besondere gebedsverhoring, sê Calvyn dat dit ons grootliks behoort aan te moedig om erns te maak met gebed. Al is dit so dat God uit sy eie baie geïnteresseerd is in ons heil en selfs nog voor ons gebore is weet wat ons behoeftes is, getuig Hy tog dat al die voorregte wat Hy aan ons meedeel, gegee word in antwoord op ons gebede. As ons dus ten spyte van sy uitnodiging ons plig versuim en nie bid nie, is ons agtelosigheid heeltemal onverskoonbaar (minime excusabilis est torpor noster, CO 37,651). Die vryheid om tot God te nader en amper vrypostig ons kwellinge na Hom te bring, is nie sommer 'n gewone voorreg nie (Komm. Jes. 38:5; CO 36,651).

Die implikasie van Psalm 34:17(18 AV) ("As die regverdiges om hulp roep, hoor die Here hulle en red Hy hulle") is duidelik: uitkoms word belowe aan dié wat tot die Here roep; dit behoort ons grootliks

16 "Modum vero praescribere, nostrum non est: quod si modum exprimimus, semper inclusa est tacita conditio" (CO 50,141). 
aan te moedig om te bid. Dit is nie God se wil dat gelowiges hulle oorgee aan luiheid nie, maar veel eerder dat hulle hulle gebede en smekinge tot Hom rig in die vaste oortuiging dat Hy die Beskermer van hulle heil is (CO 31,343).

Calvyn waarsku dat ons tog nie moet dink dat wat Jesus in Matteus 7:8 sê ("Elkeen wat vra, ontvang.") maar sommer net 'n spreekwoord is nie. Christus sê daarmee dat God uit sy eie bereid is om na ons te luister op voorwaarde dat ons tot Hom bid (modo precemur), en dat sy rykdomme vir ons beskikbaar is, op voorwaarde dat ons daarvoor vra (modo petamus). Alhoewel Hy alles verniet aan ons gee, beveel Hy ons tog om te bid om ons in ons geloof te oefen sodat Hy op ons versoek die seëninge wat uit sy onverdiende goedheid kom, aan ons kan skenk (CO 45,218).

Dit is merkwaardig hoe dikwels Calvyn sy medegelowiges veral in sy briewe en preke aanmoedig om te bid. Dit moet 'n teken wees van ons afhanklikheid en 'n bewys daarvan dat ons vir ons medemens omgee. Daarom is verwaarlosing van ons gebedslewe onverskoonbare pligsversuim.

\section{GEREELDE GEBED EN VOLHARDENDE GEBED}

Calvyn erken dat volharding in die gebed skaars en moeilik is. Juis daarom het Christus ook in die gelykenis van die weduwee en die regter sy dissipels aangespoor om te volhard in die gebed. Hy wou gelowiges daarmee juis verseker dat hulle geen vrees hoef te hê dat hulle volgehoue smekinge tot die Vader van genade geweier sal word nie (Komm. Lk. 18:1-8; CO 45,416v. Vgl. ook Komm. Ps. 44:3; CO 31,437).

So skryf hy ook aan die kerk in Genéve (1 Oktober 1538) dat hulle voor alles daaraan moet dink om waaksaam te wees in gebed en smeking, want as hulle verwagting van God is soos dit behoort te wees, kan dit nie anders nie as dat hulle harte daagliks na die hemel opgehef sal wees om Hom aan te roep en om te smeek vir die barmhartigheid wat hulle van Hom verwag ${ }^{17}$ (De Zwart 1938:36). "As daar in 
gebed nie standvastigheid en volharding is nie, bereik ons niks deur te bid nie" (Inst. 3.20.52). Ons hoef ook nie te vrees dat ons dalk te dikwels tot God bid nie. Mense mag nog verskonings aanbied as iemand hulle te dikwels iets vra, maar by God is daar nie so iets nie: Hy is altyd gereed om nuwe seëninge by die voriges te voeg, sonder einde of beperking (Komm. Jak. 1:5; CO 55,386).

Calvyn het ook die gevaar gesien dat 'n mens se gebedslewe agteruit kan gaan. Daarom, sê hy, is dit goed dat ons vir ons persoonlike godsdiensoefeninge ook sekere vaste tye moet hê, net soos die geval is met die gemeenskaplike diens van God. ${ }^{18}$ Wanneer ons dit so reël, kan dit voorkom dat ons gebedslewe tot niet gaan (Komm. Ps. 55:17-18; CO 31,542).

As een van julle wysheid kortkom, moet hy dit van God bid, en Hy sal dit aan hom gee, want God gee aan almal sonder voorbehoud en sonder verwyt (Jak. 1:5).

Vir Calvyn is die voorreg van gebed 'n voorreg wat gebruik moet

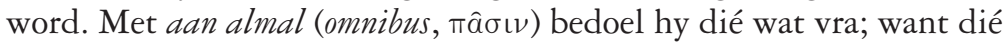
wat nie 'n hulpmiddel vir hulle behoeftes soek nie, verdien om daarin weg te kwyn. Nogtans is hierdie universele verklaring, waardeur elkeen van ons sonder uitsondering genooi word om te vra, uiters belangrik; daarom behoort niemand homself so 'n voorreg te ontneem nie (Komm. Jak. 1:5; CO 55,386).

Die voorreg van gebed is dus iets wat vir Calvyn ten nouste saamhang met selfdissipline. Juis daarom moet dit 'n vaste plek in die gelowige se dagprogram kry, waar daar nie net gebid moet word vir ons eie onmiddellike behoeftes en die van die hele Christendom nie, maar waarin daar ook volhard moet word in smeking oor sake waarvan die verhoring nog nie waargeneem is nie.

Die feit dat Calvyn telkens in sy geskrifte sy lesers verseker dat gebede wel verhoor word, is genoegsame aanduiding dat hy met pastorale bewoënheid wou aandag gee aan 'n kwessie wat by gelowiges in sy tyd ernstige vrae opgeroep het. Dat dieselfde soort vrae en dieselfde twyfel nog steeds in die harte van gelowiges leef, is seker. Daarom is 
bepaalde beskouings van Calvyn oor gebedsverhoring nie minder aktueel as in die sestiende eeu nie. Al is dit so dat sy swaar nadruk op boetvaardigheid as primêre deel van die gebed nou nie meer noodwendig aanklank sal vind by baie kerkmense nie, mag sy begronding van gebedsverhoring in die onverdiende guns van God nie ontken word nie. Sy standpunt dat God van nature die Verhoorder van gebede is, het belangrike pastorale betekenis. Wat na 'n harde woord klink — dat God ons tot ons voordeel in geduld oefen deur die verhoring van ons gebede te vertraag — word tog ook weer getemper deur sy siening dat God in sy wysheid verhoring net vertraag totdat die regte tyd daar is. Daarby kom dan ook nog die pastorale versekering dat God ons altyd verhoor, maar dikwels op 'n ander wyse as wat ons voor oë gehad het, omdat Hy ons getroue Beskermer is.

\section{BIBLIOGRAFIE}

BAtTles F L (ed.)

1978. The piety of John Calvin. Grand Rapids: Baker.

\section{CALVIN J}

1958. Tracts and treatises on the doctrine and worship of the Church (Transl. H. Beveridge) Vol. II Grand Rapids: Eerdmans. 1996. Sermons on Galatians. Albany, OR: Ages Digital Library. 2000. Selected works of John Calvin. Tracts and letters. Edited by Henry Beveridge and Jules Bonnet. Volume 4-7. Letters. Rio, WI: Ages Digital Library.

2000. Calvin's Bible Commentaries. The Ages Digital Library: Books for the Ages. Albany, OR: AGES Software.

CALVYN J

1925ff. Ioannis Calvini Opera Selecta, ed. P. Barth et al. (Munich: Kaiser).

Ioannis Calvini opera quae supersunt omnia, ed. G. Braun, E Cunitz, and E. Reuss (Braunschweig 1863-1900) (= CR 29-87).

1980. Institusie van die Christelike godsdiens 1536. (Vertaal deur H.W. Simpson.) Potchefstroom: CJBF.

1988. Institusie van die Christelike godsdiens 1559. (Vertaal deur H.W. Simpson.) Potchefstroom: CJBF. 
CO. Vide Calvyn J.

Ioannis Calvini opera quae supersunt omnia

CORPus ReFORMATORUM

Halle, Braunschweig, Berlin, Zurich, 1834-.

CR. Vide Corpus Reformatorum.

DE ZWART W

1938. Calvijn in het licht zijner brieven. Kampen: Kok.

Murray A

2004. The spiritual life. Wellington: Lux Verbi.BM.

NiESEL W

1938. Die Theologie Calvins. Einführung in die evangelische Theologie. Band VI. München: Kaiser Verlag.

OS Vide CALvYN J

Ioannis Calvini Opera Selecta.

PARTEE C H

1988. Prayer as the practice of predestination. In: W.H. Neuser (Hrsg.), Calvinus Servus Christi. Budapest: Presseabteilung des Ráday-Kollegiums.

Purves A \& Partee C 2000. Encountering God. Christian faith in turbulent times. Louisville: Westminster John Knox Press.

TYSON J R (ed.)

1999. Invitation to Christian spirituality. Oxford: University Press.

SCHOLL H

1968. Der Dienst des Gebetes nach J. Calvin. Zurich: Zwingli.

VAN DE BEEK A

2002. God's omnipotence and human freedom. In: Essentialia et Hodierna. Acta Theologica Supplementum 3:169-186.

WALLACE R S

1959. Calvin's doctrine of the Christian life. Edinburgh: Oliver \& Boyd.

Trefwoorde

Gebedsverhoring

Geloof

Wil van God
Keywords

Answering of prayer

Faith

Will of God 